\title{
Hubungan Sosial Ekonomi Orang Tua Tunggal Dengan Frekuensi Makan Dan Status Gizi Remaja
}

\author{
Socio-Economic Relations of Single Parents with The Frequency of \\ Eating and Teen Nutritional Status
}

\author{
Yessy Nur Endah Sary \\ STIKes Hafshawaty Pesantren Zainul Hasan \\ Email: yessynurendahsari@gmail.com
}

\begin{abstract}
ABSTRAK
Status orang tua tunggal mempengaruhi pola asuh terhadap anak yang beranjak remaja yang berdampak kepada status gizi anak. Pola pemberian makan orang tua kepada anak dipengaruhi oleh tingkat sosial ekonomi keluarga. Tujuan dari penelitian ini menganalisis hubungan sosial ekonomi orang tua tunggal dengan frekuensi makan dan status gizi remaja. Populasi penelitian remaja (putra/putri) usia 14-16 tahun sebanyak 91 orang. Teknik sampling dengan simple random sampling. Kriteria inklusi adalah remaja (putra/putri) yang tidak tinggal di pondok, orang tua tunggal (ayah saja atau ibu saja). Sampel dalam penelitian 87 orang. Instrumen yang digunakan kuesioner singkat tentang data demografi (umur remaja, orang tua tunggal, penyebab orang tua menjadi tunggal, pendidikan orang tua, pekerjaan orang tua). Kuesioner untuk data khusus frekuensi makan dalam sehari. Lembar observasi untuk menganalisi berat badan dan tinggi badan remaja. Analisis data menggunakan Chi Square. Hasil penelitian menunjukkan diperoleh nilai $\mathrm{p}=0,000$ berarti ada hubungan antara sosial ekonomi orang tua tunggal dengan frekuensi makan remaja dan $\mathrm{p}=0,003$ berarti ada hubungan antara sosial ekonomi orang tua tunggal dengan status gizi remaja.
\end{abstract}

Kata kunci : Sosial Ekonomi, Orang Tua Tunggal, Frekuensi Makan, Status Gizi Remaja

\section{ABSTRACT}

Parental status as a single parent affects the foster pattern of young children who have an impact on child nutrition status. The pattern of the mother's feeding to the child is influenced by education, knowledge of nutrition, economics, family support and employment. The purpose of this study was to analyze the socio-economic relationship of single parents with the frequency of eating and adolescent nutritional status. The study population was a teenager (son/daughter) aged 14-16 to 91 people. Sampling technique with simple random sampling. Inclusion criteria were teenagers (sons/daughters) who do not live in huts, single parents (father alone or mother only). Samples in the study of 87 people. The instruments used for research are brief questionnaires about demographic data (adolescence, single parents, single parent causes, parental education, parental work). Questionnaire for special data frequency meal in a day. Observation sheet to analyze the weight and height of teenagers. Analysis of research data using Chi Square. The results showed that the acquired value $P=0,000$ means there is a relationship between the social economy of a single parent with the frequency of adolescent eating and $P=0,003$ means there is a relationship between a single parent social economy with a nutritional status of teenagers.

Keywords: Socio-Economic, Single Parents, Eating Frequency, Adolescent Nutritional Status

\section{PENDAHULUAN}

Keluarga pada umumnya terdiri dari ayah, ibu dan anak (Cahyani, 2016:1-8). Akan tetapi terdapat bentuk keluarga dengan orang tua tunggal yang dijumpai dengan penyebab perceraian, kematian salah satu pasangan, kehamilan di luar nikah atau tidak mau 
menikah tetapi mengadopsi anak orang lain sehingga keluarga dapat dipimpin oleh wanita maupun pria (Usman, Cangara dan Muhammad, 2013:60-79). Jumlah orang tua tunggal di Indonesia sebanyak $18,25 \%$ dari total penduduk dan jumlahnya meningkat $0,1 \%$ setiap tahunnya. Jumlah ibu tunggal 14,84\% dan ayah tunggal 4,05\% (Monica, Widajanti dan Suyatno, 2019:373-382). Data tersebut menunjukkan bahwa jumlah anak yang tumbuh dengan orang tua tunggal juga semakin meningkat. Di Probolinggo Jawa Timur (2019) jumlah orang tua tunggal yaitu 12\% (Riyanda dan Soesilo, 2018:59-73).

Status orang tua tunggal mengakibatkan seseorang harus mampu beradaptasi dengan keadaan baru yang mempunyai peran ganda sebagai ibu sekaligus ayah atau sebaliknya dan tugas baru yang harus tetap dilaksanakan seperti mencari nafkah sendiri dan mengambil keputusan sendiri (Usman, Cangara dan Muhammad, 2013:60-79). Meskipun dengan status orang tau tunggal, ibu tunggal atau ayah tunggal harus tetap dekat dengan anak terutama anak yang mulai menginjak masa remaja agar dapat membantu mencarikan solusi pemecahan masalah yang dialami oleh anaknya (Listiyanto, 2018:49-62). Ibu tunggal atauayah tunggal tetap harus memberikan perhatian dan pola asuh yang sesuai untuk anak remajanya.

Status orang tua tunggal mempengaruhi pola asuh terhadap anak yang beranjak remaja yang berdampak kepada status gizi anak. Pola pemberian makan ibu tunggal atau ayah tunggal kepada remaja dipengaruhi oleh pendidikan dan pekerjaan yang biasa disebut dengan status sosial ekonomi keluarga (Monica, Widajanti dan Suyatno, 2019:373-382).

Sosial ekonomi keluarga mempengaruhi jumlah makanan yang tersedia yang juga akan mempengaruhi status gizi remaja (Ibrahim dan Faramita, 2014:63-75).

Perubahan perilaku remaja dengan orang tua tunggal antara lain perilaku makan yang cenderung sehat dan tidak sehat. Perilaku makan sehat yaitu konsumsi makanan sehari-hari yang mengandung karbohidrat, protein dan vitamin sesuai dengan kebutuhan zat gizi untuk dapat sehat dan produktif (Pujiati, Arneliwati dan Rahmalia, 2015:1345-1352). Perilaku makan sehat mempengaruhi status gizi remaja.

Status gizi yang baik mampu mempertahankan, memperkuat daya 
tahan tubuh, meningkatkan kemampuan fisik dan intelegensi serta produktifitas kerja (Nomate, Nur dan Toy, 2017:5157). Status gizi berkaitan dengan asupan gizi dari makanan yang dimakan baik kuantitas dan kualitasnya (Nurhaedah, Dachlan dan Nawir, 2013:169-175).

Penilaian status gizi pada remaja menggunakan antropometri yaitu indeks masa tubuh (IMT) yang berkaitan denan umur, berat badan dan tinggi badan. Klasifikasi IMT yaitu nilai Z-skor <3SD (sangat kurus), Z-skor $-3 \mathrm{sd}<-2 \mathrm{SD}$ (kurus), Z-skor -2SD sampai 1 SD (normal) (Nomate, Nur dan Toy, 2017:51-57).

Tujuan dari penelitian ini adalah menganalisis hubungan sosial ekonomi orang tua tunggal dengan frekuensi makan dan status gizi remaja.

\section{METODE PENELITIAN}

Penelitian dilaksanakan pada bulan Januari-Februari 2020 di MTS “Zainul Hasan", Genggong, Kabupaten Probolinggo. Populasi penelitian adalah remaja (putra/putri) usia 14-16 tahun sebanyak 91 orang. Teknik sampling dengan simple random sampling. Kriteria inklusi adalah remaja (putra/putri) yang tidak tinggal di pondok, tinggal dengan ayah saja atau ibu saja. Sampel dalam penelitian sebanyak 87 orang.

Instrumen yang digunakan adalah kuesioner singkat tentang data demografi (umur remaja, orang tua tunggal, penyebab orang tua menjadi orang tuatunggal, pendidikan orang tua, pekerjaan orang tua). Kuesioner untuk data khusus frekuensi makan dalam sehari. Lembar observasi untuk menganalisi berat badan dan tinggi badan remaja. Analisis data penelitian menggunakan Chi Square.

\section{HASIL DAN PEMBAHASAN}

Tabel 1. Data Sosiodemografi Remaja

\begin{tabular}{lcc}
\hline \multicolumn{1}{c}{ Sosiodemografi } & Frek & $\%$ \\
\hline Umur Remaja (tahun) & & \\
14 & 29 & 16,09 \\
15 & 40 & 45,97 \\
$16 \quad 18$ & 20,68 \\
Jenis Kelamin & & \\
Laki-laki & 35 & 40,22 \\
Perempuan & 52 & 59,73 \\
Orang Tua Tunggal & & \\
Ayah & 24 & 27,58 \\
Ibu & 63 & 70,41 \\
Penyebab Orang Tua & & \\
Tunggal & & \\
Bercerai & 28 & 32,18 \\
Meninggal & 59 & 67,81 \\
Pendidikan Orang Tua & & \\
Sekolah Dasar & & \\
Sekolah Menengah & 24 & 27,58 \\
Pertama & 48 & 55,17 \\
Sekolah Menengah Atas & & \\
Pergurun Tinggi & 8 & 9,19 \\
& 7 & 8,04 \\
Pekerjaan Orang Tua & & \\
Tidak Bekerja & 9 & 10,34 \\
Pembantu & Rumah \\
Tangga & 14 & 16,09 \\
Tukang Cuci Pakaian & 28 & 32,18 \\
\hline
\end{tabular}




\begin{tabular}{|c|c|c|c|}
\hline Pelayan Toko & & 10 & 11,49 \\
\hline Kuli Bangunan & & 13 & 14,94 \\
\hline Nelayan & & 7 & 8,04 \\
\hline Buruh Pabrik & & 4 & 4,59 \\
\hline $\begin{array}{l}\text { Pegawai Negeri } \\
\text { (PNS) }\end{array}$ & Sipil & 2 & 2,29 \\
\hline
\end{tabular}

\begin{tabular}{|c|c|c|c|c|}
\hline \multirow{2}{*}{$\begin{array}{c}\text { Freku } \\
\text { ensi } \\
\text { Makan } \\
\text { Dalam } \\
\text { Sehari }\end{array}$} & \multicolumn{4}{|c|}{ Jenis Kelamin } \\
\hline & \multicolumn{2}{|c|}{ Laki-laki } & \multicolumn{2}{|c|}{ Perempuan } \\
\hline & Frak & $\theta$ & Emot & $\theta$ \\
\hline $1 \mathrm{x}$ & 7 & 20 & 3 & 7,69 \\
\hline $2 \mathrm{x}$ & 27 & 77,14 & 42 & 80,76 \\
\hline $3 x$ & 1 & 2,85 & 7 & 13,46 \\
\hline$>3 x$ & - & - & - & - \\
\hline Total & 35 & 40,22 & 52 & 59,73 \\
\hline
\end{tabular}

Tabel 3.Status Gizi Remaja

\begin{tabular}{lcccc}
\hline \multirow{2}{*}{ Status } & \multicolumn{4}{c}{ Jenis Kelamin } \\
Gizi & \multicolumn{2}{c}{ Laki-laki } & \multicolumn{2}{c}{ Perempuan } \\
& Frek & $\%$ & Frek & $\%$ \\
\hline Sangat & 12 & 34,28 & 33 & 63,46 \\
kurus & & & & \\
Kurus & 20 & 57,14 & 14 & 26,92 \\
Normal & 3 & 8,57 & 5 & 9,61 \\
$\quad$ Total & 35 & 40,22 & 52 & 59,73 \\
\hline
\end{tabular}

Pada dasarnya, setiap orang tidak pernah berharap menjadi orang tua tunggal (Cahyani, 2016:1-8). Orang tua lengkap memiliki keuntungan dibanding orang tua tunggal sehingga mampu berbagi menyediakan kondisi dan kebutuhan sehari-hari untuk perkembangan anak yang masuki masa remaja (Listiyanto, 2018:49-62). Akan tetapi saat ini struktur dari keluarga telah mengalami perubahan yaitu adanya orang tua tunggal dengan berbagai alasan. Orang tua tunggal karena perceraian akibat ketidakharmonisan. Dampak yang dialami ibu tunggal antara lain dalam pengasuhan yang harus dilaksanakan tanpa peran ayag terhadap anakanaknya (Octaviani, Herawati dan Tyas, 2018:169-180).

Orang tua tunggal karena kematian menimbulkan kesedihan pada pasangan yang ditinggalkan dan memerlukan waktu yang lama untuk penyesuaian diri. Perubahan mengharuskan ibu menjadi satu-satunya yang bertanggung jawab terhadap kehidupan keluarga terutama masalah finansial dan mengasuh anak yang mulai menginjak masa remaja (Aprilia, 2013:268-279). Orang tua tunggal harus bekerja keras mengatasi masalah dan kebutuhan yanga ada dalam keluarganya seorang diri (Cahyani, 2016:1-8).

- Remaja yang semula hidup dengan orang tua yang lengkap kemudian tinggal dengan orang tua tunggal akan menunjukkan perubahan perilaku termasuk kebiasaan makan. Orang tua tunggal dengan hanya menjadi ibu rumah tangga yang tidak berpenghasilan mengalami masalah utama ekonomi karena tidak mampu mencukupi kebutuhan diri dan anaknya yang 
berakibat tidak terpenuhinya gizi seimbang anaknya.

Hasil penelitian menunjukkan bahwa jumlah responden perempuan 52 orang $(59,73 \%)$, lebih banyak daripada responden laki-laki 35 orang $(40,22 \%)$. Mayoritas responden berusia 15 tahun sebanyak 40 orang $(45,97 \%)$.

Mayoritas responden tinggal dengan ibu tunggal $(70,41 \%)$. Orang tua dari responden menjadi orang tua tunggal karena alasan kematian dari salah satu pasangan yaitu sebanyak 59 orang $(67,81 \%)$.

Sebagian besar orang tua dari responden berpendidikan terakhir sekolah menengah pertama yaitu sebanyak 48 orang $(55,17 \%)$. Tingkat pendidikan menentukan sifat yang positif terhadap kesehatan dan status gizi remaja (Ngantung, Pangemanan dan Gunawan, 2015:542-548). Orang tua tunggal dengan pendidikan yang lebih rendah akan lebih sulit untuk menyerap informasi tentang kebutuhan zat gizi yang diperlukan oleh remaja, kurangnya pengertian tentang makanan yang berkualitas dari berbagai jenis makanan yang dapat menimbulkan masalah gizi. Pendidikan mempengaruhi keputusan ibu untuk memberikan makanan untuk anak remaja mereka (Ibrahim dan Faramita, 2014:63-75).

Sebagian besar dari ibu tunggal responden bekerja sebagai tukang cuci yaitu sebanyak 28 orang $(32,18 \%)$. Ibu tunggal atau ayah tunggal yang sudah mempunyai pekerjaan kurang mampu memberi perhatian penuh terhadap anak remaja mereka karena kesibukan, beban kerja dan keluarga yang ditanggungnya menyebabkan kurang perhatian dalam menyiapkan hidangan yang sesuai dengan kebutuhan anak mereka. Faktor ibu atau orang tua yang bekerja menjadi penyebab belum terpenuhinya gizi remaja.

Pendapatan yang diperoleh dari bekerja mempengaruhi jenis makanan yang dikonsumsi keluarga. Keluarga dengan pendapatan rendah biasanya mengkonsumsi makanan yang lebih murah dan menu yang kurang bervariasi yang berdampak pada status gizi remaja.

Data khusus penelitian menunjukkan bahwa sebagian besar remaja laki-laki dalam sehari hanya makan sebanyak 2x $(77,14 \%)$ dan remaja perempuan juga dalam satu hari hanya makan 2x yaitu sebanyak 42 orang $(80,76 \%)$.

Remaja dari keluarga 
berpendapatan rendah secara konsisten terlihat memiliki kontrol upaya rendah dibandingkan dengan remaja dari keluarga berpenghasilan tinggi dalam hal makan (Riyanda dan Soesilo, 2018:59-73). Orang tua yang tidak bekerja dan hanya mengandalkan uang pensiun peninggalan dari suami/istri maka membuat keluarga harus berhemat yang cenderung mengkosumsi makanan dengan variasi dan gizi yang kurang cukup bahkan semua keluarga harus makan dengan frekuensi maksimal hanya 2 kali dalam satu hari karena masih banyak kebutuhan lain yang harus terpenuhi selain urusan makanan.

Pendidikan dan pekerjaan seseorang berbeda antara keluarga yang berstatus sosial ekonomi tinggi berbeda dengan keluarga dengan status ekonomi rendah (Astuti, 2016:49-58). Status sosial ekonomi orang tua mendukung terbentuknya status gizi yang baik pada remaja (Rahayu, 2011:72-80).

Sebagian besar remaja laki-laki yaitu sebanyak 20 orang $(57,14 \%)$ mempunyai status gizi sedang. Mayoritas dari remaja perempuan yaitu sebanyak 33 orang $(63,46 \%)$ mempunyai status gizi buruk.

Hasil analisis menggunakan $C h i$ Square menunjukkan nilai $\mathrm{p}=0,000$ berarti ada hubungan antara sosial ekonomi orang tua tunggal dengan frekuensi makan remaja.

Dari hasil analis dengan Chi Square diperoleh nilai $\mathrm{p}=0,003$ berarti ada hubungan antara sosial ekonomi orang tua tunggal dengan frekuensi makan remaja.

\section{SIMPULAN DAN SARAN}

Hasil penelitian menunjukkan diperoleh nilai $\mathrm{p}=0,000$ berarti ada hubungan antara sosial ekonomi orang tua tunggal dengan frekuensi makan remaja dan $\mathrm{p}=0,003$ berarti ada hubungan antara sosial ekonomi orang tua tunggal dengan status gizi remaja.

Diperlukan dukungan sosial baik dari keluarga ataupun msayarakat di sekitar tempat tinggal kepada orang tua tunggal dalam mengasuh anak remaja mereka agar kebutuhan zat gizi remaja dapat tercukupi karena remaja merupakan aset dan masa depan bangsa.

\section{DAFTAR PUSTAKA}

Cahyani. 2016. Masalah Dan Kebutuhan Orang Tua Tunggal Sebagai Kepala Keluarga. E-Journal Bimbingan Dan Kosenling Edisi 8 Tahun ke-5 2016:1-8

Usman, Cangara dan Muhammad. 2013. Kehidupan Orang Tua Tunggal. Jurnal Psikologis:60-79 
Monica, Widajanti dan Suyatno. 2019. Perbandingan Pola Asuh Dan Status Gizi Anak Usia 7-59 Bulan Antara Orang Tua Tunggal Dan Bukan Orang Tua Tunggal (Studi Di Kecamatan Pati Kabupaten Pati Provinsi Jawa Tengah Tahun 2019). Jurnal Kesehatan Masyarakat. 8(3):373-382.

Riyanda dan Soesilo. 2018. Resiliensi Anak Tunggal Yang Memiliki Orang Tua Tunggal Dengan Status Sosial Ekonomi Rendah. Psycho Idea. (1):59-73

Listiyanto. 2018. Agresivitas Remaja Yang Memiliki Orang Tua Tunggal (Single Parent) Wanita. Jurnal Psikologi Modern:49-62

Ibrahim dan Faramita. 2014. Hubungan Faktor Sosial Ekonomi Kelarga Dengan Kejadian Stunting Anak Usia 24-59 Bulan Di Wilayah Kerja Puskesmas Berombong Kota Makassar Tahun 2014. AlSihah.Publich Health Science Journal:63-75

Pujiati, Arneliwati dan Rahmalia. 2015. Hubungan Antara Perilaku Makan Dengan Status Gizi Pada Remaja Putri. JOM. 2(2):13451352)

Nomate, Nur dan Toy. 2017. Hubungan Teman Sebaya, Citra Tubuh Dan Pola Konsumsi Dengan Status Gizi Remaja Putri. Unnes Journal of Publich Health. 6(3):51-57
Nurhaedah, Dachlan dan Nawir. 2013. Status Gizi Antropometri Dan Status Hemoglobin Siswa Sekolah Sepak Bola Anyelir Dan Sekolah Sepak Bola Bangau Putra Makassar. Jurnal MKMI:169-175

Octaviani, Herawati dan Tyas. 2018. Stress, Strategi Kopinh, Dan Kesejahteraan Subjektif Pada Keluarga Orang Tua Tunggal. Jur.Ilm.Kel \&Kons. 11(3):169180

Aprilia. 2013. Resiliensi Dan Dukungan Sosial Pada Orang Tua Tunggal (Studi Kasus Pada Ibu Tunggal Di Samarainda. Jurnal Psikologi. 1(3):268-279).

Ngantung, Pangemanan dan Gunawan. 2015. Pengaruh Tingkat Sosial Ekonomi Orang Tua Terhadap Karies Anak Di Tk Hang Tuag Bitung. Jurnale-Gigi (Eg). 3(2):542-548

Astuti. 2016. Pengaruh Status Sosial Ekonomi Orang Tua, Literasi Ekonomi Dan Lifestyle Terhadap Perilaku Konsumsi Mahasswa Jurusan Pendidikan Ekonomi IKIP PGRI Bojonegoro. Jurnal Edutama:4958

Rahayu. 2011. Analisis Intensitas Pendidikan Oleh Orang Tua Dalam Kegiatan Belajar Anak, Status Ekonomi Orang Tua Terhadap Motivasi Belajar Dan Prestasi Siswa.Jurnal Pendidikan dan Pembelajaran. 18(1):72-80 